Gulawentah: Jurnal Studi Sosial

ISSN 2528-6293 (Print); ISSN 2528-6871 (Online)

Vol. 4, No. 1, Juli 2019, Hal 46-54

Tersedia Online: http://e-journal.unipma.ac.id/index.php/gulawentah

\title{
Kesenian Teledek dalam Upacara Minta Hujan di Lembeyan Magetan (Kajian Nilai Budaya dan Potensinya Sebagai Sumber Belajar Sejarah)
}

\author{
Nungky Iwana ${ }^{1}$, Muhammad Hanif ${ }^{2}$ \\ ${ }^{1}$ Pendidikan Sejarah, Universitas PGRI Madiun, Indonesia \\ ${ }^{2}$ Magister Pendidikan Ilmu Pengetahuan Sosial, Universitas PGRI Madiun, Indonesia \\ Email: iwananungky@yahoo.co.id; hanif@unipma.ac.id
}

\begin{abstract}
Abstrak
Penelitian Penelitian ini bertujuan untuk mendeskripsikan eksistensi dan latar belakang Kesenian Taledek dalam Upacara Minta Hujan di Lembeyan Magetan dan potensinya sebagai sumber belajara sejarah. Lokasi penelitian di Desa Lembeyan Wetan Kecamatan Lembeyan Kabupaten Magetan.Penelitian ini merupakan jenis deskriptif kualitatif. Teknik pengumpulan data dengan observasi, wawancara, dan dokumentasi. Teknik keabsahan data adalah trianggulasi sumber, dan analisis data menggunakan model interaktif. Kesenian Taledek merupakan seni hiburan tradisional yang dipentaskan oleh sinden (waranggana) dengan iringan alat musik jawa seperti kendang, gong, kempul, saron, centi, dan gamelan. Dalam kesenian taledek terdapat beksan (orang yang menari bersama sinden) dan memberikan saweran kepada sinden yang dimasukkan dalam wadah (baskom). Masyarakat Lembeyan Wetan Magetan saat ini masih melaksanakan upacara minta hujan pada bulan Sura dan hari Jumat legi. Masyarakat percaya akan ada hal buruk jika tidak melaksanakan upacara tersebut dan akan ada bencana di desa, aliran sungai menjadi tidak lancar, dan hasil panen berkurang. Biasanya taledek dimainkan di rumah pamong desa seperti kamituwo. Nilai budaya dalam Kesenian Taledek adalah nilai rekreatif atau hiburan, nilai religius, dan nilai sosial budaya. Upacara adat minta hujan mempunyai potensi sebagai sumber belajar sejarah yakni sebagai materi tambahan dalam pembelajaran mata pelajaran sejarah Indonesia Zaman Hindhu-Buddha.
\end{abstract}

Kata kunci: Teledek; Upacara Minta Hujan; Budaya

\section{Teledek Art at a Rainforest Ceremony (Magnetic Value Study and Its Potential as a Source of Learning History)}

\begin{abstract}
Research This study aims to describe the existence and background of Taledek's Art in the Rain Request Ceremony in Lembeyan Magetan and its potential as a source of historical learning. The location of the study was in Lembeyan Wetan Village, Lembeyan District, Magetan Regency. This research was a qualitative descriptive type. Data collection techniques with observation, interviews, and documentation. The data validity technique is source triangulation, and data analysis uses an interactive model. Taledek art is a traditional entertainment art that is performed by sinden (waranggana) with the accompaniment of Javanese musical instruments such as drums, gongs, kempul, saron, centi, and gamelan. In taledek there are beksan (people who dance together with sinden) and give saweran to sinden which is put in a container (basin). The people of Lembeyan Wetan Magetan are still carrying out rain-asking ceremonies in Sura month and Friday legi. The community believes that there will be bad things if they don't carry out the ceremony and there will be disasters in the village, the flow of the river will not be smooth, and the harvest will decrease. Usually taledek is played in the village pamongwo house like kamituwo. Cultural values in Taledek Art are recreational or entertainment values, religious values, and socio-cultural values. The
\end{abstract}

DOI: 10.25273/gulawentah.v4i1.5032

Copyright (C) 2019 Universitas PGRI Madiun

All rights reserved. 
traditional ceremony for rain has the potential to be a source of historical learning as additional material in learning the history of Indonesian Hindhu-Buddhist Age.

Keywords: Teledek; Rain Requests Ceremony; Culture

\section{Pendahuluan}

Indonesia merupakan negara multikultural yang di dalamnya terbagi ke dalam sub kebudayaan yang berbeda, masyarakat dengan kelompok ras dan suku yang beragam, dan juga berbagai macam tradisi yang unik dari tiap-tiap daerah yang ada di Indonesia, mulai dari Sabang sampai Merauke terdapat ciri khas masing-masing yang dijadikan ikon kelompok masyarakat. Keragaman suku bangsa di Indonesia menyebabkan munculnya kebudayaan yang beragam pula. Banyak kebudayaan yang berkembang di Indonesia mulai dari tradisi, adat-istiadat, kesenian, bahasa, dan juga kepercayaan yang menyebabkan masyarakat selalu memegang teguh nilai luhur yang telah diwariskan oleh nenek moyang bangsa Indonesia. Budaya merupakan suatu anugerah yang diberikan oleh Sang Pencipa kepada manusia karena manusia merupakan ciptaan yang berbeda yang mampu berpikir dengan logika, sehingga hal ini yang membedakan manusia dengan makhluk ciptaan-Nya yang lain.

Melalui budaya manusia dapat mengeksplor seluruh kreativitas, mengutarakan pendapat, mewujudkan imajinasi kedalam hal nyata bahkan dapat di apresiasi oleh masyarakat yang lain. Menurut (Anwar \& Adang, 2013) kebudayaan, secara etimologis, berasal dari kata 'Budhi' dan 'daya'. Budhi berarti kesadaran dan daya berarti kemampuan. Kemudian secara terminologis, kebudayaan dapat berarti hasil cita, rasa, dan karsa manusia yang juga merupakan pengertian umum dalam masyarakat. Sebutan 'kebudayaan' yang menunjuk kepada dunia manusia, digunakan mengingat bahwa dunia-manusia adalah dunia yang muncul berkaitan dengan aktivitas kesadaran manusia. Kebudayaan digambarkan sebagai sebuah sebutan yang menyeluruh terhadap kehidupan masusia. Dan sebagai keseluruhan, kebudayaan memiliki bagian-bagian menyusun keseluruhan tersebut. Menurut (Anwar \& Adang, 2013) menjelaskan kebudayaan adalah segala sesuatu yang diperoleh individu dari masyarakat, mencakup kepercayaan, adat-istiadat, norma artistik, kebiasaan makan, keahlian diperoleh bukan dari kreativitas sendiri melainkan merupakan warisan masa lampau yang di dapat melalui pendidikan formal atau informal.

Latar belakang masyarakat yang beraneka ragam di Indonesia memunculkan budaya yang berbeda-beda. Hal tersebut pula yang menjadikan setiap daerah di Indonesia mempunyai kebudayaan dan ciri khas yang unik dan berbeda dari satu daerah yang satu dengan daerah yang lain. Salah satu kebudayaan yang masih dilaksanakan oleh masyarakat Indonesia seperti contoh tradisi slametan, upacara adat, acara pernikahan, kelahiran, kematian, semua masih diperingati dengan kebiasaan dan kepercayaan yang dianut oleh daerah masing-masing. Di Desa lembeyan Wetan Kecamatan lembeyan Kabupaten Magetan masyarakat masih mempercayai, melestarikan, dan melaksanakan tradisi upacara adat yang berkaitan dengan mayoritas mata pencaharian masyarakat sebagai petani dan juga ada satu kebudayaan berupa seni yaitu kledhek yang juga menjadi bagian dari perhelatan acara dilaksankannya upacara adat tersebut.

Masyarakat Desa Lembeyan Wetan merupakan masyarakat yang sebagian besar penduduknya bermata pencaharian sebagai petani dan tanaman yang di tanam adalah padi. Padi merupakan sumber utama penghasilan karena sejak beberapa tahun padi memiliki harga jual tinggi dan dapat disimpan lama untuk kebutuhan konsumsi masyarakat. Tanaman padi membutuhkan banyak pengairan untuk menjaga tetap berkembang dan mendapatkan hasil (panen) yang baik. Tetapi kendala musim dan cuaca yang tidak menentu membuat masyarakat masyarakat selalu diselimuti oleh rasa cemas dan khawatir jika mereka akan gagal panen. Dari kepanikan itu masyarakat percaya bahwa tradisi upacara meminta hujan tidak boleh ditinggalkan begitu saja dan harus tetap lestari dalam masyarakat. Masyarakat melakukan tradisi ini sudah sangat lama dan memang upacara ini selalu dilaksankan oleh masyarakat karena ini merupakan peninggalan tradisi dan kekayaan budaya yang harus tetap lestari. Meskipun masyarakat Desa lembeyan Wetan adalah penganut agama Islam tetapi masyarakat tetap melaksanakan upacara meminta hujan ini karena masyarakat sudah 
mempercayai tradisi sebagai bagian dari cara untuk meminta kepada sang pencipta untuk selalu memberikan rezeki dan kelancaran disetiap kegiatan yang dilaksankaan dalam aktivitas pertanian. Terdapat pagelaran kesenian taledek setelah upacara selesai dilaksanakan untuk tujuan hiburan sekaligus penyambutan kemakmuran. Seni musik, media utamanya adalah suara yang terpadu dengan keseimbangan tiga aspek yakni irama, melodi, dan harmoni. Sementara seni tari, media utamanya adalah gerak yang terpadu dengan keseimbangan irama dan rasa (wiraga, wirama, dan wirasa). Penunjangnya ialah iringan dan ruang/latar (panggung). Pengungkapannya, karya tari dengan media gerak dan nada disebut tari. Tetapi karya tari dengan media gerak dan kata disebut drama.

Gerak tari yang terdiri dai beberapa episode dan bercerita disebut sendra tari (Sulistyo, 2005). Keseluruhan kegiatan yang dilakukan oleh masyarakat merupakan cara masyarakat untuk melestarikan kebudayaan yang ada dalam masyarakat Desa lembeyan Wetan. Kebudayaan, kesenian, adat-isiadat dan tradisi yang ada selalu dilaksanakan, tetapi sudahkah masyarakat mengetahui nilainilai dari kebudayaan yang mereka laksanakan setiap tahunnya, sudahkah masyarakat mengilhami nilai-nilai kebudayaan yang mereka lestarikan, berkaitan dengan hal tersebut, adakah nilai-nilai pelaksanaan upacara minta hujan dan kesenian kledhek ini dapat dijadikan sumber belajar sejarah mengingat sekarang banyak sekali sumber-sumber belajar yang berkembang dan bervariasi. Dengan adanya permasalahn tersebut maka terdorong untuk melakukan pengkajian lebih lanjut. Menurut (Widyastutieningrum, 2007) ledhek merupakan istilah umum yang digunakan untuk menyebut penari perempuan dalam pertunjukan tayub, sementara taledek merupakan penari wanita dalam tayub. Taledek dan tandak merupakan perempuan penari dan penyanyi jalanan, yang bermain baik disewa maupun dengan berjalan dari pintu ke pintu sepanjang jalan di kota, pasar, bahkan di desadesa. Seperti pengemis dan memang dianggap demikian. Riasan dibedaki dengan tabal-tebal, sebagai bentuk perkembangan dari pola penari topeng lama. Mereka diberi ongkos 10 sen atau 1 tali agar lekas pergi. Beberapa yang agak trampil menari tari Srimpi dan Bedaya tiruan yang jelek yang dicampur dengan unsur dari sumber rakyat. Terkadang mereka terdiri dari 2-3 gadis dan 6 pengiring gamelan. Kalau ditanggap ongkosnya Rp. 1-Rp. 2,5 per setengah jam penampilan. Gadis-gadis itu kadang juga jadi pelacur. Bentuk kesenian ini hampir seluruhnya berada di lingkaran Abangan.

Menurut (Widyastutieningrum, 2007) istilah Gambyong atau tari Gambyong mulai digunakan dalam serat Centhini yang ditulis abad XVIII. Tarian ini diperkirakan merupakan perkembangan dari tari tledhek atau Tayub. Menurut serat Sastramiruda tari Tayub ada sejak zaman Kerajaan Jenggala ( $a b a d$ XII), tari tledhek dikenal sejak zaman Demak ( $a b a d$ XV), disebut tledhek mbarangan. Bentuk pertunjukan tari taledek yang menampilkan penari dengan menyanyi tampaknya merupakan bentuk pertunjukan yang telah dilakukan sejak zaman Hinduisme. Ketika itu bentuk pertunjukan ini disebut angigel angidung. Tahun 1817, Rafles menulis mengenai adanya seorang taledhek atau ronggeng yang menari dengan sehelai selendang yang disampirkan pada salah satu bahu dengan sebuah kipas di tangan. Ronggeng itu mengiringi tari dengan menyanyi. Tarian ini merupakan tarian untuk hiburan laki-laki, baik untuk golongan atas maupun golongan bawah. Suatu pesta belum lengkap kalau belum nanggap ronggeng. Kesenian taledek mengalami pasang dan surut di setiap perkembangan zaman, hal tersebut terdapat dalam satu penenlitian yang menyatakan bahwa hasil wawancara dengan beberapa warga Desa Kiringan, Kecamatan Takeran, Kabupaten Magetan. (Novitasari \& Hanif, 2017) mengatakan bahwa pelaksanaan kesenian langen beksan atau Tayub di Desa Kiringan pada masa dahulu dengan masa kini sudah sangat berbedabaik dalam berbusana dari pada tledhek atau bersikap.

Dahulu, dalam acara tersebut selalu diwarnai dengan budaya nyawer dan mabuk-mabukan atau minum-minuman keras. Kebiasaan negatif tersebut dahulu disebut dengan tiga $\mathrm{C}$, yaitu Ciu (minuman keras), colek, dan cium sebagai unsur budaya asing yang telah mencemari kesenian Tayub yang sakral, hal tersebut selaras dengan pernyataan (Soedarsono, 2002) membeberkan dengan blakblakan ulah para teledek dan para penari pria yang ngibing atau menari bersama teledek atau ledek dalam pertunjukan tayub yang ugal-ugalan dan nakal. Dari beberapa pengertian dapat disimpulkan bahwa Kesenian Taledek merupakan perpaduan antara dua kesenian yaitu seni tari dan juga seni musik yang dibawakan secara anggun oleh penari (Waranggana atau Sinden). Kesenian yang ditampilkan oleh seorang sinden (penyanyi lagu-lagu khas jawa) diiringi dengan musik yang masih 
dengan menggunakan alat musik khas jawa pula (gong, centhi, kendang, dan masih banyak lagi). Ketika sinden membawakan sebuah lagu masyarakat yang bersedia maju di panggunng akan menarinari sambil diiringi oleh sinden yang tidak bernyanyi lainnya. Ketika selesai menari masyarakat memberikan saweran kepada sinden atau diletakkan di baskom sebagai tanda hormat dan memang sudah menjadi tradisi bahwa sinden harus disawer.

Fungsi kesenian teledek menurut (Juwariyah, 2014) mengumgkapkan bahwa awal mula istilah Gambyong tampaknya berawal dari nama seorang penari taledek. Penari yang bernama Gambyong ini hidup pada zaman Susuhunan Paku Buwana IV diSurakarta (1788-1820). Penari taledek yang bernama Gambyong itu juga disebutkan dalam buku Cariyos Lelampahanipun Suwargi R. Ng. Ronggowarsito (1803-1873), yang mengungkapkan adanya penari ledhek yang bernama Gambyong yang memiliki kemahirandalam menari dan kemerduan suara, sehingga menjadi pujaan kaum muda pada zaman itu. Sedyawati juga menyebutkan bahwa gambyong mulanya nama seorang waranggana yangamat pandai menari dan amat lincah. Nama lengkapnya Mas Ajeng Gambyong, sedangkan nama tariannya adalah Glondrong. Atas usaha K. R. M. T Wreksadiningrat, tari tersebut diperkenalkan kepada umum dan ditarikan oleh seorang waranggana. Ketika itu tariGambyong diperhalus dengan kaidah tari keraton, sehingga tari Gambyong mempunyai bentuk yang berbeda dengan sebelumnya. Disitu terjadi perpaduan tarirakyat dan tari keraton. Bentuk tari ini kemudian berkembang dalam masyarakat. Menurut (Juwariyah, 2014) tari Gambyong sering ditampilkan di Mangkunegaran pada zaman Jepang, untuk menjamu tamu pejabat tentara Jepang yang datang di Mangkunegaran (sekitar tahun 1942-1945).

Hal ini mendorong Nyi Bei Mintoraras untuk menyusun tari Gambyong Pareanom tahun 1950. Tari Gambyong ini berbeda dengan bentuk tari Gambyong sebelumnya, baik dalam susunan tari, iringantari, rias dan busananya. Bentuk tari Gambyong Pareanom disusun berdasarkan tari Srimpi, Golek, dan Gambyong. Sesuai dengan pernyataan yang disampaikan oleh (Juwariyah, 2014) perkembangan selanjutnya tari Gambyong disajikan bukan hanya untuk menyambut tamu, tetapi juga untuk berbagai hajatan yaitu dalam acara perayaan, perkawinan, pembukaan, peresmian, lomba atau festival. Gambyong Pareanom yang dilakukan oleh seluruh waranggana yang mengisi acara. Mereka yang menarikan tari Gambyong sekaligus merupakan tledhek Langen Tayub. Dari perkembangan fungsi kesenian Taledek yang telah dijelaskan oleh beberapa tokoh diatas, dapat disimpulkan bahwa fungsi kesenian Taledek pada zaman dahulu hingga masa kini terdapat dua kesamaan yaitu samasama diperankan oleh seorang perempuan dan menggunakan alat musik khas jawa sebagai pengiring lagu. Fungsi utama kesenian Taledek ini pada awalnya untuk menerima tamu dalam acara kunjungan daerah, tetapi seiring berkembangnya waktu kesenian ini semakin berkembang fungsinya bukan hanya sebagai tarian untuk menyambut tamu, tetapi sebagai kesenian yang dihelat sebagai gelar budaya pada suatu daerah, bahkan dapat dilombakan pula kesenian tari ini dalam ajang festival tari. Bukan hanya itu kesenian Taledek juga digelar pada salah satu upacara adat di berbagai daerah seperti yang dilaksanakan di Desa Lembeyan Wetan Kabupaten Magetan.

Tradisi Kesenian Tiban adalah kesenian yang berfungsi sebagai ritual memohon hujan. Tiban berasal dari kata tibo ujug-ujug. Ritual tersebut digunakan sebagai memohon hujan agar cepat turun dengan tiba-tiba. Menurut (Hidayat, 2015) Cingcowong (sebutan upacara minta hujan di daerah Kuningan) masih dilakukan karena masyarakat percaya bahwa upacara ritual ini dapat menyuburkan lahan pertanian mereka. Dari pengertian upacara minta hujan menurut kedua tokoh diatas, dapat disimpulkan bahwa pengertian upacara minta hujan adalah upacara yang dilakukan oleh masyarakat dengan berbagai ritual didalamnya yang bertujuan untuk memohon hujan kepada sang pencipta supaya hasil pertanian lebih berkah dan hasil panen melimpah. Dua aspek kehidupan (pertanian dan kepercayaan) mempengaruhi kehidupan berkesenian mereka.

Kepercayaan dan kondisi lingkungan, mata pencaharian, dan aktivitas sosial budaya masyarakat daerah tersebut tak terpisahkan dengan bentuk kesenian yang mereka selenggarakan. Masyarakat Luragun glandeuh memanfaatkan lingkungan dengan bertani. Akibatnya berbagai penyelenggaraan kesenian dan upacara adat berkaitan dengan pertanian, misalnya kesuburan tanah. Pentingnya tradisi dalam perkembangan kehidupan bangsa tak perlu diuraikan, tradisi merupakan 
akar perkembangan kebudayaan yang memberi identitas atau kepribadian suatu bangsa (Hidayat, 2015).

Tradisi ini merupakan upacara ritual kesuburan untuk memohon pada Yang Maha Kuasa agar di daerahnya diturunkan hujan. Kegiatan ini dilaksanakan satu tahun sekali pada musim kemarau. Kepercayaan masyarakat setempat seperti ini dilatarbelakangi cara berfikir warisan kebudayaan leluhurnya. Sebagaimana yang dikemukakan (Hidayat, 2015)) tentang sisa-sisa peninggalan kebudayan dulu yang disebut animisme, dimanisme, dan totemisme. Dari latar belakang yang dijelaskan beberapa tokoh tersebut, dapat disimpulkan bahwa latar belakang masyarakat melaksanakan upacara meminta hujan tidak lepas dari budaya dan kepercayaan masyarakat. Merupakan suatu budaya karena upacara ini sudah lama dilaksanakan oleh para pendahulu bangsa sehingga tradisi ini sudah tertanam dan melekat dihati masyarakat untuk terus dilaksanakan. Berkaitan dengan kepercayaan, masyarakat percaya bahwa upacara minta hujan ini akan benar-benar terjadi hujan pada saat yang diinginkan (musim kemarau), jika masyarakat tidak melaksanakan upacara ini maka tidak akan turun hujan sepanjang musim dan masyarakat (petani) akan mengalami gagal panen dan mengalami kerugian yang sangat besar.

(Setiadi, 2007) menjelaskan bahwa nilai berhubungan dengan kegiatan manusia menilai. Menilai berarti menimbang, yaitu kegiatan manusia menghubungkan sesatu dengan sesuatu yang lain, yang selanjutnya diambil keputusan. Keputusan nilai dapat berguna atau tidak berguna, benar atau tidak benar, baik atau buruk, manusiawi atau tidak manusiawi religius atau tidak religius. Penilaian ini dihubungkan dengan unsur atau hal yang ada pada manusia, seperti jasmani, cipta karsa, rasa, dan keyakinan. Cheng dalam (Setiadi, 2007) mengatakan nilai merupakan sesuatu yang sangat potensial, dalam arti, terdapatnya hubungan yang harmonis dan kreatif, sehingga berfungsi untuk menyempurnakan manusia, sedangkan kualitas merupakan atribut atau sifat yang seharusnya dimilki. Pendapat lain diungkapkan oleh darmodihardjo dalam (Setiadi, 2007) nilai adalah yang berguna bagi kehidupan manusia jasmani dan rohani. Sistem nilai termasuk pada nilai budaya, yaitu pedoman yang dianut oleh setiap anggota masyarakat terutama dalam bersikap dan berprilaku dan juga menjadi patokan dalam menilai dan mencermati bagaimana individu dan kelompok bertindak dan berperilaku. Dari pengertian beberapa hal tersebut diatas dapat disimpulkan bahwa nilai budaya merupakan pedoman yang digunakan manusia dalam bertindak, berperilaku, dan berpendapat dalam kehidupan sehari-hari supaya kehidupan berjalan dengan baik sesuai aturan yang berlaku, dan selaras dengan kebiasaan yang telah diciptakan masyarakat dalam suatu lingkungan tertentu.

Pengajaran sejarah diartikan sebagai sistem belajar mengajar sejarah. Pengajaran sejarah berkaitan dengan teori-teori kesejarahan. Berbeda dengan ilmu sejarah, pembelajaran sejarah atau mata pelajaran sejarah dalam kurikulum sekolah tidak secara khusus bertujuan untuk memajukan ilmu atau untuk mencetak calon ahli sejarah. Hal ini karena penekanan pengajaran sejarah tetap terkait dengan tujuan pendidikan umumnya yaitu ikut membangun kepribadian dan sikap mental siswa. Sutrisno Kuntoyo (dalam Saiful, 2015: 153) menyatakan bahwa kesadaran sejarah paling efektif diajarkan melalui pendidikan formal.

Hamid Hasan (dalam Saiful, 2015: 153) berpendapat terdapat beberapa pemaknaan terhadap pendidikan sejarah. Pertama, secara tradisional pendidikan sejarah dimaknai sebagai upaya untuk mentransfer kemegahan bangsa di masa lampau kepada generasi muda. Dengan posisi yang demikian maka pendidikan sejarah adalah wahana bagi pewarisan nilai-nilai keunggulan bangsa. Melalui posisi ini pendidikan sejarah ditujukan untuk membangun kebanggaan bangsa dan pelestarian keunggulan tersebut. Kedua, pendidikan sejarah berkenaan dengan upaya memperkenalkan peserta didik terhadap disiplin ilmu sejarah. Oleh karena itu, kualitas seperti berpikir kronologis, pemahaman sejarah, kemampuan analisis dan penafsiran sejarah, kemampuan penelitian sejarah, kemampuan analisis isu dan pengambilan keputusan (historical issues-analysis and decision making) menjadi tujuan penting dalam pendidikan sejarah. I Gde Widja (dalam Saiful, 2015: 153) menyatakan bahwa pembelajaran sejarah adalah perpaduan antara aktivitas belajar dan mengajar yang di dalamnya mempelajari tentang peristiwa masa lampau yang erat kaitannya dengan masa kini. Pendapat I Gde Widya tersebut dapat disimpulkan jika mata pelajaran sejarah merupakan bidang studi yang terkait dengan fakta-fakta dalam ilmu sejarah namun tetap memperhatikan tujuan pendidikan pada umumnya. 
Taufik Abdullah (dalam Saiful, 2015: 154-155) berpendapat agar siswa tidak bosan menerima materi sejarah, maka jika secara faktual yang disampaikan sama namun dalam setiap jenjang pendidikan, peristiwa tersebut akan tampil pada tingkat pengetahuan, pemahaman, serta pemberian keterangan sejarah yang semakin tinggi dan kompleks. Dengan demikian, setiap tingkatan atau tahap diharapkan bisa memberikan kesegaran dan kematangan intelektual. Dari pandangan di atas, dapat disimpulkan bahwa pembelajaran sejarah tidak mengkhususkan mempelajari fakta-fakta dalam sejarah sebagai ilmu namun perpaduan antara sejarah dan tujuan pendidikan pada umumnya. Meski demikian, pembelajaran sejarah berusaha menampilkan fakta sejarah secara obyektifmeskipun tetap dalam kerangka fakta sejarah yang sesuai dengan tujuanpendidikan itu sendiri. Dari pengertian sumber belajar yang disampaikan oleh tokoh-tokoh diatas, dapat disimpulkan bahwa pengertian sumber belajar sejarah adalah kegiatan atau aktivitas yang berhubungan dengan sejarah, aktivitas tersebut berkaitan dengan pembelajaran, kesadaran akan pentingnya sejarah yang harus diterpakan oleh masyarakat supaya masyarakat tetap berada dalam jalurnya sebagai manusia yang hidup dengan dasar sejarahnya, tidak melupakan sejarah, dan dari sejarah pula manusia dapat berkembang dengan baik sehingga terwujud insan yang bermartabat dan sesuai dengan cita-cita bangsa.

\section{Metode Penelitian}

Penelitian in dilaksanakan di Desa Lembeyan Wetan Kabupaten Magetan pada bulan Februari sampai dengan bulan Juli 2017. Penelitian ini merupakan penelitian kualitatif. Dengan jenis penelitian deskriptif. Menggunakan sumber data primer dan sekunder. Menggunakan teknik pengumpulan data obeservasi, wawancara, data dokumentasi. Instrumen penelitian berupa peneliti sendiri dan menggunakan alat bantu yang dapat memperlancar peneliti dalam memperoleh data. Sedangakn teknik

\section{Hasil dan Pembahasan}

Kesenian Taledek merupakan kesenian yang telah ada sejak zaman dulu dan selalu dipentaskan oleh masyarakat Desa Lembeyan Kabupaten Magetan dalam berbagai acara termasuk dalam tradisi upacara minta hujan juga terdapat pertunjukan Taledek di dalamnya. Tradisi ini sudah turun-temurun dilaksanakan oleh warga masyarakat sejak zaman dulu hingga sekarang. Masyarakat percaya jika melaksanakan upacara ini pasti akan mendapatkan kesenangan tetapi jika tidak melaksanakan upacara ini akan mendapatkan bencana dan dalam bertani juga tidak akan mendapatkan hasil yang baik karena akan mengalami kekeringan dan aliran sungai tidak mengalir lancar. Kesenian Taledek merupakan kesenian yang di dalamnya terdapat suatu perpaduan antara sinden, penari, musik-musik jawa (gending jawa), diiringi dengan alat-alat musik jawa gamelan seperti gong, kendang, centi, demung, saron, bonang, yang membuat pertunjukan lebih berirama dikemas menjadi pertunjukan yang menarik dan menghibur warga masyarakat. Biasanya selain bernyanyi sinden juga menari di tengah-tengah lagu yang ia bawakan. Kesenian taledek digunakan sebagai media atau alat untuk meminta hujan di Lembeyan Magetan. Upacara minta hujan adalah upacara yang dilakukan untuk meminta berkah hujan supaya masyarakat dapat segera menanam tanaman padi.

Upacara minta hujan yang dilaksanakan di Lembeyan Kabupaten Magetan tidak lain adalah karena sebagain besar masyarakat berprofesi sebagai petani, maka dari itu jika tidak melaksanakan upacara minta hujan ini masyarakat akan disusahkan hidupnya dan aliran sungai yang mengairi sawah mereka akan kering sehingga hasil panen akan berkurang.Masyarakat Desa Lembeyan Kabupaten Magetan dalam melaksanakan upacara minta hujan selalu dilengkapi dengan pertunjukan 
Kesenian Taledek karena memang sudah sejak pertama kali dilaksanakan masyarakat menggunakan Taledek. Taledek tidak boleh digantikan dengan kesenian lain jika masyarakat mengganti Taledek dengan kesenian lain maka desa akan mengalami kesusahan dan juga babad desa akan marah dan tidak mau menerimanya dengan baik, boleh dipentaskan kesenian lain seperti reyog, wayangan, ludrukan tetapi tidak dalam waktu yang sama bisa malam harinya atau dihari berikutnya. Diadakan Kesenian Taledek ini supaya masyarakat juga bisa menikmati pertunjukan yang disuguhkan juga sebagai alat untuk menyatukan masyarakat terutama untuk generasi penerus supaya tidak punah dan dapat melestarikan budaya atau tradisi dengan baik karena semakin canggihnya teknologi dan globalisasi yang semakin tidak terkendali seperti sekarang ini. Makasenda (2014:5) menyampaikan bahwa pada zaman dahulu, komunikasi tradisional dilakukan oleh masyarakat primitif dengan cara yang sederhana. Komunikasi tradisional sangat penting dalam suatu masyarakat karena dapat mempererat persahabatan dan kerja sama untuk mengimbangi tekanan yang datang dari luar. Komunikasi tradisional mempunyai dimensi sosial, mendorong manusia untuk bekerja, menjaga keharmonisan hidup, memberikan rasa keterikatan, bersama-sama menantang kekuatan alam dan pakaian dalam mengambil keputusan. Komunikasi tradisional sangat penting dalam suatu masyarakat karena dapat mempererat persahabatan dan kerja sama untuk mengimbangi tekanan yang datang dari luar. Komunikasi tradisional mempunyai dimensi sosial, mendorong manusia untuk bekerja, menjaga keharmonisan hidup, memberikan rasa keterikatan, bersama-sama menantang kekuatan alam dan dipakai dalam mengambil keputusan bersama.

Diadakan Kesenian Taledek ini supaya masyarakat juga bisa menikmati pertunjukan yang disuguhkan juga sebagai alat untuk menyatukan masyarakat terutama untuk generasi penerus supaya tidak punah dan dapat melestarikan budaya atau tradisi dengan baik karena semakin canggihnya teknologi dan globalisasi yang semakin tidak terkendali seperti sekarang ini. Upacara minta hujan di Lembeyan Magetan dilaksanakan mulai dari pagi sampai dengan siang atau bahkan selesai sore hari. Prosesi peaksanaan upacara minta hujan sendiri yaitu ketika pagi ibu-ibu sudah menyiapkan hidangan yang diperlukan untuk selamatan di ndauhan, biasanya sebelum selamatan dimulai sudah ada beberapa warga yang sudah di Ndauhan bersiap untuk menyembelih dua kambing yang kepalanya digunakan untuk sesembahan untuk danyang yang menunggu Ndauhan atau sungai tersebut. Setelah prosesi penyembelihan kambing selesai maka tibalah saatnya untuk melaksanakan acara selamatan, selamatan dipimpim oleh orang dituakan oleh masyarakat, tugas dari pemimpin upacara adalah memimpin doa meminta supaya Tuhan memberikan kelancaran dalam menanam padi, memohon supaya diberikan pengairan yang lancar tidak ada kekeringan dan seluruh kegiatan bertani dapat terlaksana dengan baik tidak ada kendala.

Nilai budaya yang terkandung dalam Kesenian Taledek adalah nilai rekreatif atau hiburan, nilai religius, dan nilai sosial budaya. Berbicara mengenai nilai tentu saja terdapat nilai-nilai yang terkandung dalam Kesenian Taledek pada pelaksanaan upacara minta hujan yang dilaksankaan di Lembeyan Kabupaten Magetan yaitu kesenian taledek merupakan kesenian yang mempunyai nilai hiburan, didalam kesenain taledek terdapat pertunjukan seni tari, seni musik, perpaduan antara senin musik dan tari, yang membuat kesenian taledek masih digemari oleh masyarakat. Kesenian Taledek mempunyai nilai estetik atau keindahan di dalam setiap gerakan tarian, nyanyian-nyanyian lagu Jawa yang dibawakan mengandung keindahan yang tidak bisa dilakukan oleh orang lain, maka dari itu pertunjukan ini juga berfungsi untuk mengenalkan budaya-budaya Indonesia di kancah Internasional.

Kesenian taledek dalam upacara minta hujan di Lembeyan Kabupaten Magetan merupakan peninggalan kebudayaan dan salah satu tradisi yang sudah dilaksanakan oleh nenek moyang sejak zaman dahulu. Tradisi ini tidak serta merta hilang dan dilupakan begitu saja oleh masyarakat Desa Lembeyan Kabupaten Magetan, justru masyarakat selalu antusias dan selalu melaksanakan tradisi 
setiap tahunnya. Dalam upacara ini terkandung banyak sekali hal-hal yang dapat digunakan sebagai sumber belajar sejarah. sumber belajar sejarah adalah pembelajaran sejarah atau mata pelajaran sejarah dalam kurikulum sekolah memang tidak secara khusus bertujuan untuk memajukan ilmu atau untuk menelorkan calon ahli sejarah, karena penekanannya dalam pengajaran sejarah tetap terkait dengan tujuan pendidikan pada umumnya yaitu ikut membangun kepribadian dan sikap mental siswa. Sutrisno Kuntoyo (dalam Saiful, 2015:153) menyatakan bahwa kesadaran sejarah paling efektif diajarkan melalui pendidikan formal. Hamid Hasan (dalam Saiful, 2015:153) berpendapat, terdapat beberapa pemaknaan terhadap pendidikan sejarah. Pertama, secara tradisional pendidikan sejarah dimaknai sebagai upaya untuk mentransfer kemegahan bangsa di masa lampau kepada generasi muda. Pembelajaran sejarah yang dapat diamil dalam penelitian ini yakni kesenian taledek merupakan warisan budaya sekaligus peninggalan sejarah yang harus dilestarikan oleh generasi penerus, kebanyakan generasi sekarang kurang mengetahui kebudayaan atau tradisi lokal sehingga jika tidak dijadikan materi tambahan di dalam materi pembelajaran bukan tidak mungkin Kesenian Taledek akan terganti dengan kebudayaan modern yang sudah banyak menjalar di kalangan generasi penerus sekarang ini. Bukan hanya Kenian Taledek saja tetapi juga tradisi masyarakat dalam melaksanakan upacara minta hujan pada masyarakat Desa Lembeyan Kabupaten Magetan juga merupakan salah satu contoh penerapan silabus pembelajaran yang diterapkan oleh pemerintah sejarah kelas X (sepuluh) semester 1 (satu) pada BAB Indonesia Zaman-Buddha: Silang Budaya Lokal dan Global Tahap Awal dengan materi pokok Bukti-bukti kehidupan pengaruh Hindu-Buddha yang masih ada pada saat ini, terdapat di KD 3.6 menganalisis karakteristik kehidupan masyarakat, pemerintahan, dan kebudayaan pada masa kerajaan-kerajaan Hindu-Buddha di Indonesia dan menunjukkan contoh bukti-bukti yang masih berlaku pada kehidupan masyarakat Indonesia masa kini (Silabus SMA/MA/SMK/MAK Akrab Senada, Mata pelajaran Sejarah Wajib Kelas X).

\section{Simpulan}

Kesenian Taledek merupakan suatu seni hiburan tradisional yang dipentaskan oleh sinden (waranggana) dengan iringan alat musik jawa seperti kendang, gong, kempul, saron, centi, selain itu ada alat musik jawa (gamelan) sebagai pengiring lagu yang dibawakan oleh sinden. Dalam kesenian taledek juga terdapat beksan atau orang yang menari bersama sinden dan beksan tersebut harus memberikan saweran kepada sinden yang dimasukkan ke dalam wadah (baskom). Di Lembeyan Wetan Kabupaten Magetan Kesenian Taledek biasanya digunakan sebagai alat atau media untuk meminta hujan, meski begitu Kesenian Taledek tidak hanya dipentaskan dalam upacara minta hujan saja tetapi juga pada acara-acara besar lainnya seperti temu manten, sunatan, wayangan, dan malam resepsi tujuh belas agustusan. Masyarakat Lembeyan Wetan Kabupaten Magetan hingga saat ini masih melaksanakan upacara minta hujan pada bulan Sura dan pada hari Jumat legi.

Biasanya masyarakat menyebut upacara dengan sebutan "slametan urung-urung " ada juga yang menyebut dengan "slametan neng ndauhan". Masyarakat melaksanakan upacara minta hujan karena upacara ini sudah turun-temurun dilaksanakan mulai zaman dahulu dan tentu saja masyarakat tidak ingin meninggalkan budaya yang telah ada begitu saja sehingga tradisi ini masih tetap ada dan lestari sampai dengan saat ini. Masyarakat percaya bahwa akan ada hal-hal buruk yang terjadi jika tidak melaksanakan upacara minta hujan. maka akan ada bencana di desa, aliran sungai menjadi tidak lancar, dan hasil panen akan berkurang. Prosesi pelaksanaan upacara minta hujan yakni dimulai pada pagi hari ibu-ibu menyiapkan hidangan yang digunkaan untuk selamatan di ndauhan atau sungai yang menjadi aliran utama atau sumber utama pertanian di Lembeyan Wetan Magetan. Setelah siap pagi-pagi sekali selamatan dimulai dan dipimpin oleh penghulu desa, biasanya setelah selamatan selesai acara dilanjutkan dengan penyembelihan dua ekor kambing tepat di pusat sungai dan darah kambing dialirkan ke dalam aliran sungai tersebut bersama dengan kepala kambing juga ikut di larung atau dihanyutkan ke dalam sungai. 
Masyarakat Desa lembeyan Kabupaten Magetan merupakan masyarakat yang diwarisi berbagai macam kebudayaan oleh nenek moyang salah satunya adalah kesenian taledek dan tradisi melaksanakan upacara mintahujan. Meskipun masyarakat sampai sekarang masih melaksanakan tradisi upacara minta hujan dan kesenian taledek, tetapi tidak sedikit pula generasi yang belum mengetahui makna bahkan diwaktu kapan dan untuk apa tradisi tersebut dilaksanakan. Maka dari itu penting bagi generasi tua untuk memberikan pendidikan warisan budaya ini, kepada generasi muda bahkan sejak dini harus sudah mulai dikenalkan warisan budaya desa supaya generasi penerus tidak merasa asing dan dapat melaksanakan dan meneruskan tradisi dengan baik. Terutama Kesenian Taledek karena kesenian ini memerlukan banyak latihan dalam pemestasannya seperti menyinden dan juga bermain alat musik jawa yang sedikit rumit (berbeda dengan memainkan alat musik modern) akan lebih banyak membutuhkan banyak untuk pengenalan dan latihan memainkannya.Kesenian Taledek merupakan kesenian yang sudah ada dan masih berkembang sampai dengan sekarang. Masyarakat Desa Lembeyan Kabupaten biasanya menggelar acara Taledekan saat ada perhelatan upacara minta hujan yang berfungsi supaya dilancarkan pertaniannya, tidak ada bencana di desa, dan masyarakat dapat hidup tentram.Seharusnya dengan digelarnya acara ini rutin setiap tahun dapat dimanfaatkan pemerintah lokal daerah menjadikan Lembeyan sebagai desa wisata dan wisatawan baik lokal maupun dari dari luar daerah dapat menyaksikan prosesi upacara minta hujan dan juga pagelaran Taledek. Sehingga dengan dibukanya desa wisata budaya maka selain desa Lembeyan akan dikenal oleh masyarakat desa lain pastinya juga akan menambah pemasukan desa dengan menerapkan sistem tiket kepada pengunjung yang ingin menyaksikan upacara minta hujan dan pagelaran Kesenian Taledek.

\section{Daftar Pustaka}

Anwar, Y., \& Adang, A. (2013). Sosiologi untuk Universitas. Bandung: Refika Aditama.

Hidayat, L. M. (2015). Cingcowong: Upacara Ritual Meminta Hujan di Desa Lurangung Landeuh Kecamatan Luragung Kabuapten Kuningan. Jurnal Ekpresi Seni: Jurnal Ilmu Pengetahuan Dan Karya Seni, 17(2), 195-205.

Juwariyah, A. (2014). Konstruksi Langen Tayub Nganjuk dalam Perspektif Bergerian. Jurnal Budaya Nusantara, 1(2), 126-135.

Lestariningsih, N., \& Suardiman, S. P. (2017). Pengembangan Bahan Ajar Tematik-Integratif Berbasis Kearifan Lokal Untuk Meningkatkan Karakter Peduli Dan Tanggung Jawab. Jurnal Pendidikan Karakter, 7(1). https://doi.org/10.21831/jpk.v7i1.15503

Novitasari, R. T. A., \& Hanif, M. (2017). Tari Kecetan dalam Tradisi Keduk Beji Desa Tawun Kecamatan Kasreman Kabupaten Ngawi (Makna Simbolis Dan Sumber Pembelajaran Sejarah Lokal). Agastya: Jurnal Sejarah Dan Pembelajarannya, 7(1), 49-65. https://doi.org/10.1017/CBO9781107415324.004

Nugroho, D., Prihantanto, A., \& Pratikto, I. (2014). Kabupaten Kendal Sebagai Objek Wisata Rekreasi Pantai, 3(November 2013), 332-341.

Setiadi, E. M. (2007). Ilmu Sosial dan Budaya Dasar. Jakarta: Kencana.

Soedarsono, R. . (2002). Seni Pertunjukkan di Era Globalisasi. Yogyakarta: Gdjah Mada University Press.

Sulistyo, T. E. (2005). Kaji Dini Pendidikan Seni. Surakarta: UNS Press.

Suryawan. (2016). Peran Kelompok Sadar Wisata (Pokdarwis) Sendang Arum dalam Pengembangan Potensi Pariwisata (Studi Kasus Di Desa Wisata Tlahap Kecamatan Kledung Kabupaten Temanggung). Jurnal Elektronik Mahasiswa PLS, 5(6), 143-152.

Widyastutieningrum, S. R. (2007). Penulisan kritik tari. Surakarta: Pengembangan Ilmu Budaya bekerjasama dengan ISI Press Surakarta. 